argues against, on the grounds of his immense reliance on Western orthodoxy to universalize African humanist thoughts.

No doubt, Left Universalism, Africacentric Essays is a timely, multivocal intervention that opens up a wide range of issues that cuts across disciplines. The interdisciplinary approach and vast intertextual references make the book an invaluable asset. It would serve as a great introductory text on methodology for drawing on a wide range of disciplines to create a niche and multiple sites of contestations for scholars in the social sciences and the humanities. Ato Sekyi-Otu has produced a highly cerebral book that will arguably set in motion other areas of research that seek to position Africa as the center of value. I will be revisiting how I think about Afropolitanism, my current area of research, from this notion of universalism.

Oladipupo Oyeleye University of Wisconsin, Madison @oyeleye@wisc.edu

\title{
"A Surreal World": Enigmatic Hermeneutics and the Ethical Turn in Left Universalism, Africacentric Essays
}

Ato Sekyi-Otu's Left Universalism, Africacentric Essays poses a provocative question: is it possible to outline an African universalist metaethical system based on the preexisting structures of African social, political, and economic life? In this book, Sekyi-Otu addresses this possibility and traces a universal system of values that has its origins in the local, indigenous practices of African peoples but that is, a priori, transcultural in its scope. In spite of its rather modest title, it mounts a methodical and often times polemical defense of universalism and its attending family of concepts with an emphasis on the culture and values of Africa as a postcolonial space. The text's mission is ambitious, and at times the exposition a bit unwieldy, but Sekyi-Otu's theoretical breadth, which encompasses a vast archive of philosophy, political science, sociology, postcolonial studies, Marxism, critical theory, and literary studies, is marshalled towards a radical act of retrieval-the left retrieval of universalism - in order to theorize a new foundationalism capable of addressing the realities of postcolonial life. Sekyi-Otu's "visionary foundationalism" (26) seeks to uncover the preexisting universalism which undergirds the African ethical life, to combat the view that universalism and its attendant concepts are merely an "imperialist Eurocentric hoax" (viii) imported to the Continent. Further, the book underscores the necessity of this kind of foundationalist ethical positioning in any radical, future-oriented politics, thus reviving and recasting debates within and about African socialism from the 1950s and 1960s. Addressing his defense to both the Western academic modes of ethical thinking grounded in Rortyan anti-foundationalism and postcolonial schools of thought stemming from deconstruction, Sekyi-Otu underlines the necessity of (re)turning to a 
moral realism grounded in the particularities of postcolonial African life and the shared ethical values which emanate from it.

This retrieval itself is Africacentric in that it acknowledges what Sekyi-Otu refers to as a "homemade" metacritical principle, arguing that "indigenous ethical judgments are always already universalizing in their justificatory grounds, inescapably humanist in their critical vocabulary" (18). Thus, he proposes the "possibility of a metalanguage of assertion and justification of moral claims" which is "indigenous in its provenance and 'semantic resources,' bears the marks of historical contingency and cultural context, and yet is transcultural in its presuppositions and consequences" (20). Within these indigenous practices and culturally specific ethical metalanguages, Sekyi-Otu discerns the humanist impulse of universalism, defined as "the criticism or vindication of an arrangement and a convention, an idea and a practice, an event and an action: the justification or confutation of a moral assertion and a claim, a belief and a principle, in the inquiring name of the human and human universals" (3). Thus, Sekyi-Otu looks to proverbs as one useful form of ethical thinking around which the arguments of the book accumulate, like the Akan proverb from which the first chapter derives its name: "Is She Not Also a Human Being?" Coupled with this Africacentric philosophical archive, the book produces a thorough metacritical analysis of Western and African academic conversations in universalist ethics.

Sekyi-Otu's erudition and synthetic abilities are remarkable-there are 196 footnotes in the first chapter alone-and his readings of scholarship with which he disagrees seemed always to be generous and faithful. However, this vast theoretical archive can result in, at times, overlooking the contexts and conversations which his many references participate in. For instance, Sekyi-Otu suggests that the ethical musing of Sam Harris offers a "nuanced version of moral realism as a general proposition" (52n143). However, while Harris's The Moral Landscape appears to be an objective, disinterested probing of the role of science in ethical thinking, indeed suggesting science as the basis for moral realism, it quickly becomes apparent that belying Harris's interest in science's neutrality is nothing more than a kind of pedantic, sophomoric rationalism borne of the same Enlightenment universalism that spurred European imperialism. ${ }^{1}$

Sekyi-Otu's reference to Harris speaks more, I think, to a dearth of reasoned and ethically-sound forays into articulating and retrieving the notion of universalism $^{2}$ and ultimately lends credence to the text's guiding heuristic of uncovering regionally- and ideologically-inflected universalist perspectives that do not collapse under their own contradictions. The final chapter, "Enigmas and Proverbs," proposes what I find to be the text's most compelling contribution; in it, SekyiOtu outlines a mode of reading that returns to the "visionary foundationalism" proposed in "Is She Not Also a Human Being?" Based on the formal properties of proverbs, their performative exchange and open-endedness, the chapter offers a hermeneutic of enigmatic reading, a mode of interpretation which attends to the particularities of African reality: "Homeland of the brutal enigma and its twin, the absurd, in its most soul-corroding forms" (236). He sees in this enigma a challenge: "Can contemporary African literary culture teach the world anything about apprehensions of the human condition in history?" (236). The challenge 
has bested many critics of African literature who have disparaged it as too eminently political and thus far too atomized and unapproachable. Sekyi-Otu suggests that this myopic position arises out of a certain Western academic perspective that does not see in the African world the "carnival, ecstasy of excess, fortunate indeterminacy" that it finds in other postcolonial settings. Instead, "in the actually existing lands from whose historical experience this affair of the mind is allegedly distilled, the postcolonial condition reeks of the rancid odor of this bitter earth and its products: determinate desolation and indeterminate hope" (240).

It is around these two products-desolation and hope-that enigmatic reading, or what the subheading calls the "Poetics of Real Enigmas," orbits. Sekyi-Otu derives this mode of reading from his comparative analysis of Ngugi wa Thiongo's Petals of Blood and Ayi Kweh Armah's The Beautyful Ones Are Not Yet Born. Ngugi, he suggests, confronts the turbulence caused in the wake of the end of formal colonization with "a tradition of world-making, living evidences of shared understandings achieved by dint of exacting praxis, the remembrance of things cultivated in concert by forebears and contemporaries" (249; my emphasis). Therefore, while the crisis of how to make a world out of the ashes of history in Petals of Blood is located in "the mystery of things in social space," Armah asks what happens to things in "historical and political time, troubling questions of their identity, sameness or distinctness-temporal evidences of difference-that sets in motion a sense of metaphysical wonder and provokes proverbs of the human condition" (250). One of the primary enigmatic qualities Sekyi-Otu identifies in Armah's novel is the tendency to represent time as "deprived of its normal division into past, present and future, dispossessed of narratable moments of beginning, middle and ending" (253). This dispossession results in the monotonous procession of daily life, of the world made "indecipherable" and "foundationless, despoiled of distinguishable forms and qualities after the fleeting iridescence of history" (265). Furthermore, this deprivation expresses the peculiar "strangeness," 3 in Tejumola Olaniyan's formulation, of the African state, not as atomized exception, an asterisk to an otherwise triumphant world capitalist order and thus utterly elusive to the western reader, but in fact as expressing a central aspect of human existence in a world seemingly devoid of meaning or justice.

For Sekyi-Otu, the proverb is a "vision of possibility" capable of representing just such jarring contradictions (271). It is precisely that cultural form which both exposes this strangeness and accepts its correlate instability as a moment of opportunity for the "adamant refusal of 'sure knowledge' as the foundation of human self-understanding" (271). Proverbs emanate from the particular forms of social and cultural exchange that such strangeness necessarily engenders in the lives of Africans; the proverb form therefore operates in this enigmatic register through their rhetorical openness. Sekyi-Out calls this the "teleopoeisis" of the proverb: "an invitation to the infinite work of possibility" (273). Echoing his assertions about the universal nature of ethical thinking in African contexts, he suggests that the proverb is capable of addressing the indeterminacy of postcolonial existence, but that its refusal of "metaphysical determinism" is what makes it such an attractive candidate as a basis for interpreting an African universalist worldview (265). This is not simply a matter 
of finding an "ethnic peculiarity" or a "distinctive African commonality," vulgar anthropologisms that dismiss more than they explain (274). Rather, these are instances of "local universals" predicated upon the lived experiences of "postcolonial humanity" which take shape in the proverbial form (274-75). While it may be the case that the directive rhetoric of "metaphysical determinism," the language of stability and closure that African novels tend to resist, purports to assuage the daily drama of "a world choking with harrowing and unfathomable mysteries," for Sekyi-Otu the "exacting enigma of the proverb," its very mysteriousness, is the only possible riposte to the "surreal world" of African life (274).

In conclusion, Sekyi-Otu's enigmatic hermeneutic strikes me as Left Universalism's most compelling contribution, especially to conversations in literary studies, where debates about distant/close and paranoid/reparative reading practices and the continued relevance of the very "sword of critique" itself have long riveted the field. ${ }^{4}$ The enigmatic mode of reading does not seem to harbor the depth metaphor eschewed by distant reading nor the antagonistic valences that critics of the hermeneutics of suspicion attribute to criticism in the paranoid mode. This mode of reading does not seek to unravel or penetrate the enigmatic, it welcomes its honest depiction and the responses of people in their mundane and exceptional encounters with it. In Left Universalism, enigmatic reading focuses particularly on proverbs because of the active social life they experience: localized and particular responses to ethical questions that contain certain universal conceptions about a shared humanity. But these proverbs are simply one manifestation of cultural responses to the enigmatic quality of African life, and Sekyi-Otu's work impels literary critics to see African literature as addressing more than the immediately local, national or even regional concerns that gave cause to its specific content but as encompassing the whole human world of shared scarcity and abundance.

\section{Notes}

1. For Harris's close association between "science" as he conceives it and the Enlightenment, see Pangburn Philosophy, "Sam Harris \& Jordan Peterson - June 23, 2018," YouTube, August 31, 2018, https://www.youtube.com/watch?v=jey_CzIOfYE. For his ethical reasoning with regards to US interventionism abroad, see Sam Harris, "The Limits of Discourse." Last modified May 1, 2015. https://samharris.org/the-limits-ofdiscourse/\#47.

2. I see kindred attempts, though by necessity more limited, in the materialist-oriented literary criticism of, for instance, Fredric Jameson's The Political Unconscious: Narrative as a Socially Symbolic Act, which Sekyi-Otu refers to often, and related texts like Nicholas Brown's Utopian Generations: The Political Horizon of Twentieth-Century Literature and Jed Esty's A Shrinking Island: Modernism and National Culture in England.

3. Tejumola Olaniyan, "State and Culture in Africa: The Possibilities of Strangeness," in State and Culture in Postcolonial Africa: Enchantings (Bloomington: Indiana University Press, 2017), 5.

4. The most representative of these debates and the thinking they engender can be found in Rita Felski, The Limits of Critique (Chicago, IL: University of Chicago Press, 2015); Franco Moretti, Graphs, Maps, Trees: Abstract Models for a Literary History (Brooklyn, NY: Verso, 2005); Eve K. Sedgwick, "Paranoid Reading and Reparative Reading, or, 
You're So Paranoid, You Probably Think This Essay Is About You," in Touching Feeling: Affect, Pedagogy, Performativity (Durham, NC: Duke University Press, 2003).

\section{References}

Brown, Nicholas. Utopian Generations: The Political Horizon of Twentieth-Century Literature. Princeton: Princeton University Press, 2009.

Esty, Jed. A Shrinking Island: Modernism and National Culture in England. Princeton: Princeton University Press, 2014.

Felski, Rita. The Limits of Critique. Chicago, IL: University of Chicago Press, 2015.

Harris, Sam. "The Limits of Discourse." Sam Harris. Last modified May 1, 2015. https://samharris.org/the-limits-of-discourse/\#47.

Jameson, Fredric. The Political Unconscious: Narrative as a Socially Symbolic Act. Ithaca: Cornell University Press, 2013.

Moretti, Franco. Graphs, Maps, Trees: Abstract Models for a Literary History. Brooklyn: Verso, 2005.

Olaniyan, Tejumola. "State and Culture in Africa: The Possibilities of Strangeness." In State and Culture in Postcolonial Africa: Enchantings. Bloomington: Indiana University Press, 2017.

Pangburn Philosophy. "Sam Harris \& Jordan Peterson - June 23, 2018." YouTube, August 31, 2018. https://www.youtube.com/watch?v=jey_CzIOfYE.

Sedgwick, Eve K. "Paranoid Reading and Reparative Reading, or, You're So Paranoid, You Probably Think This Essay Is About You." In Touching Feeling: Affect, Pedagogy, Performativity, 123-52. Durham: Duke University Press, 2003.

Ivan Babanovski

University of Wisconsin, Madison

님obanovski@wisc.edu

(C) 2019 Ivan Babanovski https://doi.org/10.1080/21674736.2019.1594864

\section{Author's response}

\section{Collins's comradely caveats}

1. I do seem (with Armah) to reject Big Time Teleology, only to replace it with the story of "a society that is teleological at every point insofar as it is the result of choice ... suffusing every moment in the history of human society with its own telos." From unitary historical teleology to finite articulations of telos throughout history; telos pluralized but telos all the same, a pluralistic teleology, so to speak. Is my comrade exploiting the dual meanings of telos: telos as informing design and telos as immanent goal or purpose? "The result of choice" may conceivably be called telos in the first sense (I'd prefer to describe it as a constraining project ("project" in the Sartrean sense) but probably not in the second?

2. Distinguishing between communism as capitalism's consummation or patrimony and communism as "the negation of capitalism"; or conversely put, capitalism 